\title{
The Effect Of The Implementation Of The 2013 Curriculum On Mathematics Learning Outcomes Of N.1 High School Students STU Jehe Pakpak Bharat Regency From 2015 - 2018
}

\author{
Elsida Aritonang ${ }^{1)}$, Nova Erawati Sidabalok ${ }^{2)}$ \\ ${ }^{1,2}$ Program Studi Pendidikan Matematika, Universitas Efarina \\ elsidaaritonang@gmail.com
}

\begin{abstract}
Based on the list of Mathematics grade X grade students from T.P 2015/2016 to T.P $2017 / 2018$, there can be seen many significant and positive changes with an increase in students' mastery learning from $40.87 \%$ to $48.72 \%$ to $80.85 \%$. In addition to increased learning completeness, the average student learning outcomes in mathematics also increased. There is a change in the involvement of students to discuss and cooperate with fellow friends in terms of solving problems given by the teacher. Changes in the activity of students to take part in learning mathematics. The seriousness of students in participating in learning has also increased. The activeness of students in answering oral questions has also increased. This is indicated by the increasing number of students who give correct answers. the activeness of students in completing homework is increasing. This is indicated by the increasing frequency of students completing homework on time. The activeness of students to appear in front of the class solving problems on the board also increased. Students begin to believe in themselves and have the ability to solve the problems given. Based on observation, the teacher has a problem where the students are very familiar with the conventional way, the teacher explains in front of the class while students listen, Building a conducive classroom atmosphere by involving students to be more active sometimes inviting a commotion in the classroom where students initially play more than learn. Building a sense of responsibility to students also becomes difficult because students' demands actually become reversed because the teacher explains a little subject matter and students are directed to further develop material insights through discussion activities and so on. The application of the 2013 curriculum also requires students to understand the implementation of the value of the knowledge acquired so that a variety of practical activities are needed as a tangible form of the implementation of students' mathematical knowledge.
\end{abstract}

Keywords: Curriculum 2013, Teacher Constraints, Learning Outcomes

\section{INTRODUCTION}

Some curriculum experts argue that the heart of education is in the curriculum. Good and bad educational outcomes are determined by the curriculum, whether able to build critical awareness of students or not. The term curriculum is used in education because the curriculum is closely related to efforts to develop students in accordance with the objectives to be achieved. So that the curriculum has several important aspects such as planning learning experiences, the program of an educational institution which is realized in a document as well as the results of the implementation of the documents that have been prepared. Harsono (2016: 27) Revealed that the curriculum is an educational idea expressed through practice. While the 2013 curriculum is an implementation of Law no. 32 
of 2013. The 2013 curriculum is more emphasized on character education, especially at the elementary level, which will be the foundation for the next level. Through the development of a 2013 curriculum that is based on character and competence, we hope that this nation will become a dignified nation, and its people will have added value, and selling value that can be offered to others in the world, so that we can compete, compete and even compete with other nations in global order. This is possible, if the implementation of the 2013 curriculum can truly produce a productive, creative, innovative, and characterized human being (E. Mulyasa, 2013: 7)

Based on the explanation there, the researchers assumed that the reason for developing the 2013 curriculum was in response to future challenges such as globalization, convergence of science and technology. However, in implementing the 2013 curriculum there were still obstacles as stated by Handayani (2015) that the implementation of the 2013 Curriculum in MAN 2 Banjarmasin Model still contained constraints, namely in the implementation of the learning process, teachers had difficulty adjusting learning activities with the RPP made by MGMP, the use of a scientific approach is not optimal, the composition of the material in mathematics (specialization)

The implementation of the 2013 High School Curriculum places mathematics as the subject (maple) with the highest portion of hours compared to the previous curriculum in Indonesia. Mathematics is in compulsory subject groups, specializations, and electives. The curriculum developers in 2013 seemed to give a sign and affirmation of the importance of mathematics in the school curriculum, this raises questions and analysis for the writer wanting to research more deeply to find out "the effect of applying the 2013 curriculum on student learning outcomes in Pakpak Bharat"

This study generally aims to obtain a picture of the effect of the implementation of the 2013 curriculum on the students' dramatic learning outcomes at Pakpak Bharat High School. While specifically this research aims:

(1)To find out whether the application of the 2013 curriculum has an influence on student mathematics learning outcomes. (2) To find out what are the obstacles encountered by teachers in applying the 2013 curriculum to student learning outcomes

Seeing the improvement in student learning outcomes and the obstacles encountered by teachers through the implementation of the 2013 curriculum is urgent in this study.

\section{RESEARCH METHOD}

In this study, qualitative research is used with the post-facto method (field data collection) and case studies. Qualitative research is a research procedure that produces descriptive data in the form of written or oral words from people and observable behavior (Bogdan and Tylor, 1990). Qualitative research is related to the ideas, perceptions, opinions, or beliefs of the people studied, all of which cannot be measured by numbers. Qualitative research aims at obtaining a complete picture of a matter according to the human point of view studied. 
The method used in this research is expost facto namely data collection on Mathematics learning outcomes and case studies where researchers try to find out how the influence of the 2013 Curriculum on students' mathematical learning outcomes and the obstacles encountered by teachers when applying them in SMA N.1 STU Jehe Kab . Pakpak Bharat from the 2015/2016 Academic Year 2017/2018. According to Robert Yin, case studies are empirical inquiry that investigates phenomena in real life contexts, when the boundaries between phenomena and contexts do not appear explicitly, and where multiple sources of evidence are utilized. Case studies focus more on or attempt to answer "how" and "why" questions, and to some extent also answer "what" questions, in research activities (Burhan Bungin, 2005).

Researchers collected data and described the effect of the 2013 curriculum on students' mathematical learning outcomes and the obstacles encountered when teachers applied them in SMA N.1 STU Jehe Kab. Pakpak Bharat according to the actual situation that occurred at the study site.

The research will be carried out in January 2018 in SMA N.1 STU students in Jehe District. Pakpak Bharat Even semester which is currently located on Jln. Great Subbulussalam Pakpak Bharat.

The scope of the study is limited to the effect of the application of the 2013 Curriculum in mathematics to the mathematical learning outcomes of students of SMA N.1 STU Jehe Kab. Pakpak from the 2015/2016 - 2017/2018 Learning Year towards the same students and the obstacles experienced by mathematics teachers when applying the 2013 curriculum.

Mathematics students and teachers in ST N.1 High School Jehe Pakpak Bharat from the 2015/2016 Academic Year - 2017/2018 is the subject of this study. Students used as research samples are different students during the 2015/2016 - 2017/2018 learning period throughout class $X$ for three periods and the research variables in this paper include: (1) Students' mathematical learning outcomes after applying the 2013 Curriculum from the 2015 Learning Year / 2016 - 2017/2018, (2) Obstacles found by teachers in the implementation of the 2013 Curriculum at SMA N 1 STU Jehe Pakpak Bharat from the 2015/2016 Academic Year - 2017/2018. While data analysis techniques include: Data Collection, Data Reduction, Data Presentation and Drawing Conclusions

\section{RESULT AND DISCUSSION} Improved Student Learning Outcomes

Table 1. Description of T.P 2015/2016 Student Learning Outcomes

\begin{tabular}{llc}
\hline $\mathbf{N}$ & Statistik & $\begin{array}{l}\text { Angka } \\
\text { Statistik }\end{array}$ \\
\hline 1 & Jumlah Siswa & 115 \\
\hline 2 & $\begin{array}{l}\text { Kriteria Ketuntasan } \\
\text { Minimal }\end{array}$ & 70 \\
\hline
\end{tabular}




\begin{tabular}{llc}
\hline 3 & Tuntas & 47 \\
\hline 4 & Belum Tuntas & 68 \\
\hline 5 & Nilai Terendah & 46 \\
\hline 6 & Nilai Tertinggi & 74 \\
\hline 7 & Rata-rata (Mean) & 60,81 \\
\hline 8. & Varians & 23,57 \\
\hline 9 & Simpangan Baku & 5,54 \\
\hline
\end{tabular}

As can be seen from the table above shows that Mathematics learning outcomes obtained by students in the 2015/2016 Academic Year have an average value of 60.81 , with a variance of 23.57 and a standard deviation (standard deviation) of 5.54. There were 47 students who completed, while 68 students out of 115 were not complete. The highest score obtained by students is 70 and the lowest grade is 45, while the Minimum Completion Criteria (KKM) for Mathematics in Class $\mathrm{X}$ is 70 .

Table 2. Classification of Mathematics Value of Class X T.P 2015/2016 Students

\begin{tabular}{|c|c|c|c|}
\hline $\begin{array}{l}\text { Rentan } \\
\text { g Nilai }\end{array}$ & $\begin{array}{l}\text { Katego } \\
\text { ri }\end{array}$ & $\begin{array}{l}\text { Frekuens } \\
\text { i (orang) }\end{array}$ & $\begin{array}{l}\text { Presentas } \\
\mathrm{e}\end{array}$ \\
\hline $0-35$ & $\begin{array}{l}\text { Sangat } \\
\text { Rendah }\end{array}$ & 0 & $0.00 \%$ \\
\hline $36-69$ & Rendah & 74 & $64,34 \%$ \\
\hline Tidak & Tuntas & 74 & $64,34 \%$ \\
\hline $70-79$ & Sedang & 41 & $35,65 \%$ \\
\hline $80-89$ & Tinggi & 0 & $0.00 \%$ \\
\hline $\begin{array}{l}90- \\
100\end{array}$ & $\begin{array}{l}\text { Sangat } \\
\text { Tinggi }\end{array}$ & 0 & $0.00 \%$ \\
\hline \multicolumn{2}{|c|}{ Tuntas } & 41 & $35,65 \%$ \\
\hline \multicolumn{2}{|c|}{$\begin{array}{l}\text { Nilai Di atas } \\
\text { Rata-rata }\end{array}$} & 17 & $14,78 \%$ \\
\hline \multicolumn{2}{|c|}{$\begin{array}{l}\text { Nilai Di bawah } \\
\text { Rata-rata }\end{array}$} & 98 & $85,22 \%$ \\
\hline \multicolumn{2}{|c|}{ Total } & 115 & $100 \%$ \\
\hline
\end{tabular}

From the information in Table 4.3 above, it can be concluded that there are $47.83 \%$ (55 students) in the category of values below the average and as many as $52.17 \%$ (60 students) are in the category of values above the average. For more details, the following is a histogram on the learning completeness of class X T.P 2015/2016 
Table 3. Description of T.P 2016/2017 Student Learning Outcomes

\begin{tabular}{lll}
\hline No & Statistik & $\begin{array}{l}\text { Angka } \\
\text { Statistik }\end{array}$ \\
\hline 1 & Jumlah Siswa & 117 \\
\hline 2 & $\begin{array}{l}\text { Kriteria Ketuntasan } \\
\text { Minimal }\end{array}$ & 70 \\
\hline 3 & Tuntas & 57 \\
\hline 4 & Belum Tuntas & 60 \\
\hline 5 & Nilai Terendah & 50 \\
\hline 6 & Nilai Tertinggi & 79 \\
\hline 7 & Rata-rata (Mean) & 68,81 \\
\hline 8. & Varians & 20,57 \\
\hline 9 & Simpangan Baku & 4,54 \\
\hline
\end{tabular}

The above table shows that Mathematics learning outcomes obtained by students in the 2016/2017 Learning Year have an average value (mean) of 68.81, with a variance of 20.57 and the standard deviation (standard deviation) is 4.54 . There were 57 students who completed, while 60 students out of 117 were not complete. The highest score is 79 students and the lowest score is 50, while the Minimum Criteria in Mathematics Subjects in Class X is 70

Table 4. Classification of Mathematics Value of Class X T.P 2016/2017 Students

\begin{tabular}{|c|c|c|c|}
\hline $\begin{array}{l}\text { Rentang } \\
\text { Nilai }\end{array}$ & $\begin{array}{l}\text { Kategor } \\
\text { i }\end{array}$ & $\begin{array}{l}\text { Frekuen } \\
\text { si } \\
\text { (orang) }\end{array}$ & $\begin{array}{l}\text { Presenta } \\
\text { se }\end{array}$ \\
\hline $0-35$ & $\begin{array}{l}\text { Sangat } \\
\text { Rendah }\end{array}$ & 0 & $0.00 \%$ \\
\hline $36-69$ & Rendah & 60 & $51.28 \%$ \\
\hline Tidak & untas & 60 & $51.28 \%$ \\
\hline $70-79$ & Sedang & 57 & $48.72 \%$ \\
\hline $80-89$ & Tinggi & 0 & $0.00 \%$ \\
\hline $\begin{array}{c}90- \\
100\end{array}$ & $\begin{array}{l}\text { Sangat } \\
\text { Tinggi }\end{array}$ & 0 & $0.00 \%$ \\
\hline \multicolumn{2}{|c|}{ Tuntas } & 57 & $48.72 \%$ \\
\hline \multicolumn{2}{|c|}{$\begin{array}{l}\text { Nilai Di atas Rata- } \\
\text { rata }\end{array}$} & 19 & $16.24 \%$ \\
\hline \multicolumn{2}{|c|}{$\begin{array}{l}\text { Nilai Di bawah } \\
\text { Rata-rata }\end{array}$} & 98 & $83.76 \%$ \\
\hline \multicolumn{2}{|c|}{ Total } & 117 & $100 \%$ \\
\hline
\end{tabular}


From the information in Table 4.3 above, it can be concluded that there are $83.67 \%$ (98 students) in the category of values below the average and as many as $16.24 \%$ (19 Students) are in the category of values above the average

Descriptive Analysis of Student Learning Outcomes in 2017/2018 Learning Year

Table 5. Description of Student Learning Outcomes T.P 2017/2018

\begin{tabular}{llc}
\hline No & Statistik & $\begin{array}{l}\text { Angka } \\
\text { Statistik }\end{array}$ \\
\hline 1 & Jumlah Siswa & 141 \\
\hline 2 & $\begin{array}{l}\text { Kriteria } \\
\text { Ketuntasan } \\
\text { Minimal }\end{array}$ & 70 \\
\hline 3 & Tuntas & 114 \\
\hline 4 & Belum Tuntas & 27 \\
\hline 5 & Nilai Terendah & 67 \\
\hline 6 & Nilai Tertinggi & 80 \\
\hline 7 & $\begin{array}{l}\text { Rata-rata } \\
\text { (Mean) }\end{array}$ & 71,51 \\
\hline 8. & Varians & 7,01 \\
\hline 9 & Simpangan & 2,65 \\
& Baku & \\
\hline
\end{tabular}

The above table shows that Mathematics learning outcomes obtained by students in the 2017/2018 Academic Year have an average value of 71.51, with a variance of 7.01 and a standard deviation (standard deviation) of 2.65. There are as many as 114 students complete, while 27 students out of 141 have not yet completed. The highest score was 80 and the lowest score was 67 , while the Minimum Criteria in Mathematics Subjects in Class X was 70

Table 6. Classification of Mathematics Values of Class X T.P 2017/2018

\begin{tabular}{cccc}
\hline $\begin{array}{c}\text { Rentang } \\
\text { Nilai }\end{array}$ & $\begin{array}{c}\text { Kategor } \\
\mathrm{i}\end{array}$ & $\begin{array}{c}\text { Frekuen } \\
\text { si } \\
\text { (orang) }\end{array}$ & $\begin{array}{c}\text { Presentas } \\
\mathrm{e}\end{array}$ \\
\hline $0-35$ & $\begin{array}{c}\text { Sangat } \\
\text { Rendah }\end{array}$ & 0 & $0.00 \%$ \\
\hline $36-69$ & Rendah & 27 & $19.15 \%$ \\
\hline Tidak & Tuntas & $\mathbf{2 7}$ & $\mathbf{1 9 . 1 5 \%}$ \\
\hline $70-79$ & Sedang & 113 & $80.14 \%$ \\
\hline $80-89$ & Tinggi & 1 & $0.71 \%$ \\
\hline $90-$ & Sangat & 0 & $0.00 \%$ \\
\hline 100 & Tinggi & &
\end{tabular}




\begin{tabular}{|ccc|}
\hline Tuntas & $\mathbf{1 1 4}$ & $\mathbf{8 0 . 8 5 \%}$ \\
\hline $\begin{array}{c}\text { Nilai Di atas Rata- } \\
\text { rata }\end{array}$ & 44 & $31.21 \%$ \\
\hline $\begin{array}{c}\text { Nilai Di bawah } \\
\text { Rata-rata }\end{array}$ & 97 & $68.79 \%$ \\
\hline Total & $\mathbf{1 4 1}$ & $\mathbf{1 0 0 \%}$ \\
\hline
\end{tabular}

From the information in Table 4.6 above, it can be concluded that there are $68.79 \%$ (97 students) in the category of values below the average and as many as $31.21 \%$ (44 students) are in the category of values above the average.

\section{Discussion}

Based on the list of Mathematics grade $\mathrm{X}$ grade students from T.P 2015/2016 to T.P 2017/2018, many significant and positive changes can be seen. Some of these changes can be reviewed one of them in terms of the level of completeness of student learning as in the summary table of the following level of student learning completeness. Outcomes

Table 7. Summary of Completeness of Student Mathematics Learning

\begin{tabular}{|c|c|c|c|c|c|c|c|}
\hline $\begin{array}{l}\mathrm{N} \\
0\end{array}$ & $\begin{array}{l}\text { Kategori } \\
\text { Ketuntas } \\
\text { an }\end{array}$ & $\begin{array}{c}\text { T.P } \\
2015 / 201 \\
6\end{array}$ & $\begin{array}{c}\text { Persen } \\
\text { tase } \\
\text { Jumla } \\
\text { h } \\
\text { Siswa }\end{array}$ & $\begin{array}{c}\text { T.P } \\
2016 / 201 \\
7\end{array}$ & $\begin{array}{c}\text { Persenta } \\
\text { se } \\
\text { Jumlah } \\
\text { Siswa }\end{array}$ & $\begin{array}{c}\text { T.P } \\
2017 / 201 \\
8\end{array}$ & $\begin{array}{c}\text { Persents } \\
\text { se } \\
\text { Jumlah } \\
\text { Siswa }\end{array}$ \\
\hline 1 & Tuntas & 47 & $\begin{array}{c}40,87 \\
\% \\
\end{array}$ & 57 & $48,72 \%$ & 114 & $80.85 \%$ \\
\hline 2 & $\begin{array}{l}\text { Belum } \\
\text { Tuntas }\end{array}$ & 68 & $\begin{array}{c}59,13 \\
\%\end{array}$ & 60 & $51,28 \%$ & 27 & $19.15 \%$ \\
\hline & Total & 115 & $\begin{array}{c}100.0 \\
0 \%\end{array}$ & 117 & $\begin{array}{c}100.00 \\
\%\end{array}$ & 141 & $\begin{array}{c}100.00 \\
\%\end{array}$ \\
\hline
\end{tabular}

Indicates the level of mastery learning students have increased. Student learning outcomes in the 2015/2016 TP were only 40.87\%, Student learning outcomes in the $2016 / 2017 \mathrm{TP}$ were only $48.72 \%$ of the total students while in the TP 2017/2018 students who completed were increased to $80.85 \%$ from overall student. This shows the achievement of student learning outcomes there was a significant increase during the implementation of Curriculum K13. Meanwhile the level of student learning outcomes can be seen in the following table

\begin{tabular}{|l|l|c|c|c|}
\hline No & Statistik & $\begin{array}{c}\text { T.P } \\
2015 / 2016\end{array}$ & $\begin{array}{c}\text { T.P } \\
2016 / 2017\end{array}$ & $\begin{array}{c}\text { T.P } \\
2017 / 2018\end{array}$ \\
\hline 1 & Nilai rata-rata & 60,81 & 68,81 & 71,51 \\
\hline 2 & Nilai Tertinggi & 74 & 79 & 80 \\
\hline & Nilai Terendah & 46 & 50 & 67 \\
\hline
\end{tabular}


From the table and graph in the picture above shows a picture of the achievement of student learning outcomes are increasing. The highest score obtained by students in TP 2015/2016 is 47 The highest score obtained by students in TP 2016/2017 is 79 while the highest value in TP 2017/2018 is 80 . Similarly, the lowest score in TP 2015/2016 is 46, the lowest value on TP $2016 / 2017$ is 50, in TP 2017/2018 it increased to 67 and. On an average it also experienced a very significant increase ie in T.P 2016/2017 the average value was 68.81, while in T.P 2017/2018 it increased to 71.51 .

During the K 13 curriculum there has been a significant increase in student learning outcomes. Likewise, changes in student activity in following the learning process. This change has been noted through the results of student observations by the subject teacher concerned during the teaching and learning process. The changes are as follows:

Changes in student involvement to discuss and cooperate with peers in solving problems given by the teacher. Changes in the activity of students to take part in learning mathematics. At the beginning there were still many students who were less active and enthusiastic, after making changes in accordance with the demands of the 2013 curriculum it turned out that the students became interested and their enthusiasm increased. The seriousness of students in participating in learning has also increased, this is indicated by the seriousness of the students in active problem solving (questions) given by the teacher. By giving group responsibilities to students, they are more serious about learning and competing in solving the problems given.

The activeness of students in answering oral questions is also increasing. This is indicated by the increasing number of students who give correct answers. Likewise the activeness of students in completing homework is increasing. This is indicated by the increasing frequency of students completing homework on time The activeness of students to appear in front of the class completing questions on the board also increased. Students begin to believe in themselves and have the ability to solve the problems given.

However, in order to achieve these changes many of the obstacles faced by Mathematics Teachers in implementing the 2013 curriculum were to be accepted by students and to improve student learning outcomes. Some of the obstacles are as follows:

In the 2013 curriculum, students are required to be more active and the teacher acts as a facilitator or supervisor. Students must find their own learning problems and find the best solutions for themselves. In this case, the teacher has a problem where the students are very familiar with the conventional way that the teacher explains in front of the class while students listen. The teacher gives an example, the student writes, the teacher gives the questions according to the example, then the student answers the questions given by the teacher, and so on. Many students feel hesitant and awkward in teaching their peers in each group. As a realization the teacher provides understanding and motivates students to dare to express their opinions. After taking action, students begin to get used to teaching their peers or group members. 
Building a conducive classroom atmosphere by involving students as a whole to be more active sometimes inviting a commotion in the classroom where students initially play more than learning.

Building a sense of responsibility to students also becomes difficult because students' demands actually become reversed because the teacher explains a little subject matter and students are directed to further develop material insights through discussion activities and so on. This becomes an obstacle because there is always a reason students blame the teacher for giving little material so students feel they don't understand and need more time to work on responsibilities such as homework assignments. In addition, the application of the 2013 curriculum also requires students to understand the implementation of the value of the knowledge acquired so that various practical activities are needed as a tangible form of the implementation of students' Mathematical knowledge. This is also a condition that is not used to students, so it makes it more difficult to learn to achieve learning objectives with the time available. So sometimes the subject matter is pushed back so that students can comfortably accept the learning situation demanded by the 2013 curriculum.

However, various obstacles and situations mentioned above can be accepted by students and finally students are more happy in learning activities compared to conventional methods. Students turned out to be more active and student learning outcomes to be improved as has been presented in this study. That is, this study provides the conclusion that the 2013 curriculum has a positive impact on student learning outcomes especially in class X T.P 2015/2016 - T.P 2017/2018 where there is a very significant and positive improvement.

\section{CONCLUSION}

(1)There is a positive and significant effect of the application of 2013 Curriculum on Mathematics learning in class X T.P 2015/2016 - T.P 2017/2018 with an increase in student learning completeness from $40.87 \%$ to $48.72 \%$ to $80.85 \%$. In addition to increased learning completeness, the average student learning outcomes in Mathematics also increased, namely in TP 2015/2016 the average learning outcomes of 60.81 in 2016/2017 TP the average student learning outcomes increased to 68.81 increased in TP 2017 / 2018 to 71.51.

(2)There are obstacles in the implementation of the 2013 curriculum in Mathematics subject class X TP 2015/2016 to TP 2017/2018, many students are hesitant and awkward to more actively ask questions and find learning material, students initially feel less responsible, the classroom atmosphere is not very conducive because discussion activities as a form of ways for students to find their own learning solutions and student learning time which was initially difficult to be effective and efficient towards the learning objectives to be achieved because students need more time to get used to the 2013 curriculum learning patterns. 


\section{REFFERENCES}

Adisusilo, Sutarjo. (2012). Pembelajaran Nilai Karakter Konstruktivisme dan VCT Sebagai Inovasi Pendekatan Pembelajaran Afektif. Jakarta: Rajagrafindo Persada

Depdiknas. (2003). Undang-undang RI No.20 tahun 2003.tentang sistem pendidikan nasional.

Depdiknas. (2008). "Kamus Besar Bahasa Indonesia". Gramedia Pustaka Indonesia

Sevilla, Consuelo dkk. (1993). Pengantar Metode Penelitian. Jakarta: UI-Press.

Handayani, Titin. (2015). Kendala Implementasi Kurikulum 2013 Pada Mata Pelajaran Matematika Kelas X Di Man 2 Model Banjarmasin Tahun Pelajaran 2015/201. Banjarmasin:

Kemendikbud. (2015). Peraturan Menteri Pendidikan dan Kebudayaan, Nomor 58, Tahun 2015, tentang Kurikulum 2013 Sekolah Menengah Pertama (SMP) / Madrasah Tsanawiyah (MTs).

Lickona, Thomas. (2013). Pendidikan Karakter: Panduan Lengkap Mendidik Siswa Menjadi Pintar dan Baik. Bandung: Penerbit Nusa Media

Mulyasa. (2013). Pengembangan dan Implementasi Kurikulum 2013. Bandung: PT Remaja Rosdakarya

Muslich, Masnur. (2011). Pendidikan Karakter: Menjawab Tantangan Krisis Multidimensional. Jakarta: PT Bumi Aksara.

Peraturan Menteri Pendidikan Dan Kebudayaan Republik Indonesia Nomor 104 Tahun 2015 tentang Penilaian Hasil Belajar Oleh Pendidik Pada Pendidikan Dasar Dan Pendidikan Menengah. Jakarta: Menteri Pendidikan Dan Kebudayaan Republik Indonesia.

Permendikbud Republik Indonesia Nomor 69 (2013). Tentang Kerangka Dasar dan Struktur Kurikulum Sekolah Menengah Atas/Madrasah Aliyah.

Sagala, Syaiful. (2014). Konsep dan Makna Pembelajaran. Bandung: Alfabeta.

Samsuri. (2011). Pendidikan Kewarganegaraan sebagai Wahana Membangun Karakter Bangsa. Yogyakarta: UNY Press

Sailor \&. Galen dan William Alexander. (1994). Planning curriculum for scholl. New York: Holt Rine heart and Wingstons. Inc

Slameto. (2015). Belajar dan faktor-faktor yang mempengaruhinya. Cetakan Keenam. Jakarta: PT Rineka Cipta.

Syatibi, Rahmat Raharjo. (2013). Pengembangan dan Inovasi Kurikulum. Yogyakarta: Azzagrafika

Sanjaya, Wina. (2014). Strategi Pembelajaran, Jakarta: Kencana Prenada Media Group

Wibowo, Agus. (2012) Pendidikan Karakter strategi Membangun Karakter Bangsa Berperadaban, Yogyakarta, Pustaka Pelajar. 